\title{
Influence of the margin of error due to the use of aerial photographs on the interpretation of the shoreline changes: Three cases of study (Atlantic coast of Morocco)
}

\section{Khalid EI KHALID ( $\nabla$ elkhalidi_khalid@yahoo.fr)}

Université Chouaib Doukkali Faculté des Sciences https://orcid.org/0000-0003-2889-3210

\section{Mehdi Maanan}

Universite Hassan II de Casablanca Faculte des Sciences Ain Chock

Mounir Hakkou

Universite Mohammed V de Rabat

Bendahhou Zourarah

Universite Chouaib Doukkali Faculte des Sciences

Research Letter

Keywords: Aerial photographs, Shoreline, Error margin, Sandy beach, Accretion, Erosion.

Posted Date: April 10th, 2020

DOI: https://doi.org/10.21203/rs.3.rs-20949/v1

License: (c) (1) This work is licensed under a Creative Commons Attribution 4.0 International License.

Read Full License 


\section{Influence of the margin of error due to the use of aerial photographs on the}

2 interpretation of the shoreline changes: Three cases of study (Atlantic coast

3 of Morocco)

4 Khalid EL Khalidi ${ }^{\mathrm{a}, *}$, Mehdi Maanan ${ }^{\mathrm{b}}$, Mounir Hakkou ${ }^{\mathrm{c}}$ and Bendahou Zourarah ${ }^{\mathrm{a}}$

5 a Marine geosciences and sol sciences Laboratory, Associated Unit URAC 45, University of

6 Chouaib Doukkali, B.P. 20, 24000 El Jadida, Morocco.

7 b Earth Sciences Department, Faculty of Sciences Ain Chock, University Hassan II, 8 Casablanca, Morocco

$9{ }^{\mathrm{c}}$ Earth Sciences Department, Scientific Institute, University Mohamed-V, Rabat, Morocco

$10 *$ Corresponding author: elkhalidi_khalid@yahoo.fr

Keywords: Aerial photographs, Shoreline, Error margin, Sandy beach, Accretion, Erosion.

13

14

15

16

17

18

19

\section{Abstract}

In mesotidal environments, the monitoring of shoreline changes is hampered by the determination of this line on aerial photographs. This paper discusses and evaluates the importance of taking into account the margin of error associated in determining the state of the shoreline.

To demonstrate this effect, three cases were selected and studied using aerial photographs from 1946 and 2016 (70-year period). The sites chosen on the Moroccan Atantic coast are very close to each other but evolve differently. We proved statically that the impact of taking into account the margin of error will not have the same effect on the interpretation of the results.

By taking these errors into consideration, the interpretation of the results becomes more consistent and more suitable for the decision-makers. 


\section{Introduction}

Sandy beaches are coastal areas that constantly changing; they can retreat (erosion) or advance (accretion), depending on natural or anthropogenic factors. Changes can be related to local factors (geology, geomorphology, wind...), marine forcing agents (waves, tides, currents, and sea-level), but also the state of human intervention (habitat, port, dyke...), with complex scale-dependent interactions (Brown et al., 2006, Hulme et al., 2002; Gibeaut, 2000).

One of the most important aspects that need to be investigated is study of historical shoreline dynamics. Aerial photography has been creating a good data base for the compilation the coast where the shoreline position has changed (Murray F., 2013; Fletcher et al., 2003; Anders et al., 1991; Crowell et al., 1991; Stafford, 1971). Shoreline position interpreted from historical aerial imagery is frequently used to assess shoreline change (Wernette and al., 2017).

The importance of the vertical aerial photographs (black and white) is that they are documents that can give us the state of the shoreline (in the old years) before the development of computer technology and satellite imagery. Therefore, the use of aerial photographs is essential for the study of the historical shoreline states.

On an aerial photograph, to monitor coastal changes, identification of the following morphological components of the shore may prove important (Furmanczyk and DudzinskaNowak, 2019): High water line (border between the land and the sea); dune base line/cliff food line and cliff range line/dune crest line.

The high water line (HWL) has been demonstrated to be the best indicator of the land-water interface for historical shoreline comparison studies (Xiaojun, 2009, Pajak, M.J., and Leatherman, 2002); it can usually be approximated from aerial photographs (Dolan and Hayden, 1983; Stafford, 1971). Fortunately, the HWL is usually evidenced on black and white aerial photographs by a change in gray tone (Boak and Turner 2005, Crowell et al., 1991). 
53 Durand (1999) and Romine et al. (2009) identified five potential sources of error margin in 54 the position of the shoreline interpreted from aerial photographs, being: 1) the precision of the reference document, 2) the precision of the location of control points, 3) the errors related to the polynomial models used by the software, 4) the errors on the exact position of shoreline, 5) the errors related to the fluctuations exact of the shoreline.

Therefore, the use of aerial photographs is strongly linked to the data and software used, to the environmental conditions and to the operator. The margin of error is calculated from the combination of all these elements.

In this paper we want to show that the consideration or not of the margin of error has a strong influence on the interpretation of the results, especially in the case of beaches where the coastline evolves slowly.

For this purpose, we have chosen three sites that evolve differently; the beach of Sidi Moussa, the north-eastern part and the south-western part of Sidi Abed bay (Moroccan Atlantic coast). We calculated the evolution of their shorelines using aerial photographs from 1946 and 2016 (70 years).

\section{The Study Area}

The study area is a part of Moroccan Atlantic coastline $\left(32^{\circ} 57^{\prime} 30^{\prime \prime} / 33^{\circ} 30^{\prime} 30^{\prime \prime} \mathrm{N}\right.$; $\left.08^{\circ} 46^{\prime} 45^{\prime \prime} / 08^{\circ} 41^{\prime} 15^{\prime \prime} \mathrm{W}\right)$. It is characterized by his remarkable landscape richness (fig. 1). The area is a series of sandy beaches of Quaternary age (Ouadia, 1998), separated by rocky coastlines from transgressive plioquaternary deposits (Gigout 1951).

73 The two sites chosen are sandy coastlines; they are close to each other $(10 \mathrm{~km})$. They have the

74 same geological characteristics, they are subject to the same weather conditions and they have 75 the same offshore marine conditions. However, they are morphologically different. 
The site of Sidi Moussa is a rectilinear sandy beach, about 2,900 m long. It is limited to the South-West by a rocky point and to the North-East by a sandy spit that marks the pass of the lagoon of Sidi Moussa.

The bay of Sidi Abed is a sandy beach subdivided into two parts by a tombolo. The northeastern part is $1,500 \mathrm{~m}$ long and the south-eastern part is about $950 \mathrm{~m}$ long. Several villas are built on the dune of the north-eastern part and this site is very coveted by the national tourist in summer.

The region's climate is semi-arid with an annual average temperature of about $18.7{ }^{\circ} \mathrm{C}$ and a pluviometry annual average of $317 \mathrm{~mm}$.

According to Koutistonsky et al (2006), the mean annual winds have speeds ranging from 4 to 9 m.s-1, with predominantly northeasterly and northerly directions. The strongest winds are observed from December to February, from the west and northwest, with speeds more than 30 m.s-1. The weakest winds occur during the summer and are predominantly from the north and northeast.

The tide is semi-diurnal with two high tides and two low tides approximately every 25 hours with a tidal range of between $2 \mathrm{~m}$ and $4 \mathrm{~m}$ (Hilmi et al. 2002).

The waves $\mathrm{W}$ and NW are almost permanent. The amplitudes range between 0.5 to 7 meter and the periods vary between 8 to 18 seconds (Chaibi, 2003). The highest waves $(10-11 \mathrm{~m})$ come from the west and the longest waves (12-13 seconds) come from the northwest and north (Koutistonsky et al, 2006).

\section{Methods}

The shoreline is extracted from vertical aerial photographs (black-and-white) taken in 1946 and 2016 (Scanned at high resolution $600 \mathrm{dpi}$ ). This documents were superimposed in the same geographical reference frame using a topographical map (lambert conform conical) (tab. 1). 
101 The aerial photographs are processed (georeferenced and corrected) using the image

102 processing software TNTmips and then exported to the Arc-Gis software for shoreline 103 digitization and cartographic representation (fig. 2).

104 The rectification of aerial photographs is done by locating the coordinates of as many 105 common points (A minimum of 20 geographically distributed ground control points). These

106 landmarks are distributed over the entire photograph to obtain a coherent result (Bertier, 107 2009).

108 In order to best correct defects related to internal distortions in aerial photos, it is necessary to

109 use geometric deformation models. The model used is called 'Affine model'.

110 Following, the resampling process we used called 'Nearest Neighbor model' permitted us to

111 determine the numerical value to be placed in the new pixel location of the corrected output 112 image.

113 The chosen shoreline (high water line, HWL) is the boundary between wet and dry sand

114 (wet/dry line) evident by a tonal contrast. This boundary represents the upper reach of the 115 wave swash during the preceding high tide and is less susceptible to daily changes in ocean 116 water levels, which are not related to shoreline changes, than the water line (Boak and Turner 117 2005, Crowell et al., 1991).

118 The principal methodological approach recommended in the draft FEMA (The United States

119 Federal Emergency Management Agency) guidelines is to digitize historical and current 120 shorelines from maps and aerial photographs so that transects, plotted perpendicular to the 121 shorelines, can be created for the purpose of measuring and computing rates of shoreline 122 change (In Crowell et al., 1991). We've plotted perpendicular transects every 45 meters for 123 the beach of Sidi Moussa (65 transects) and for the bay of Sidi Abed (56 transects).

124 The overall uncertainty (the error margin) is the sum of all errors incurred during data pre125 processing operations (tab. 2). These errors may be combined by calculating the square root 
126 of the sum of the squares of the standard deviations. The rootmean-square total error (RMST),

127 is given by Equation (Sutherland 2012) :

$$
R M S T=\sqrt{ }\left(R M S S^{2}+R M S I^{2}+R M S V^{2}\right)
$$

128 Where: RMSS is the root-mean-square source uncertainty (RMSE of the base image),

129 RMSI is the root-mean-square interpretation uncertainty (Interpretation error),

130 RMSV is the root-mean-square variability error (RMSE of the georeferencing process).

131 A more appropriate accuracy standard is RMST95, which is calculated by Equation (FGDC 132 1998, In Wernette and al., 2017):

$$
\text { RMST95 }=1.7308 * R M S T
$$

133 RMST95 indicates the distance below which $95 \%$ of the positional errors in the image are 134 expected to fall (Wernette and al., 2017).

135 The results obtained from the RMST95 indicate that this value does not exceed $12 \mathrm{~m}( \pm 6 \mathrm{~m})$

136 (tab. 2). This result is found by several authors (Durand, 1999; Dial 2000, Gaillot et al., 137 2001).

138 In order to compare our results, without and with taking into account the margin of error, the

139 value of $\pm 6 \mathrm{~m}$ was used to create the buffer zone for each shoreline.

\section{Results and Discussion}

141 For the three cases of study, the shoreline dynamics (erosion/accretion) will be expressed in

142 linear meter $(\mathrm{Lm})$ and surface area $\left(\mathrm{m}^{2}\right)$. These results will be analyzed taking into account

143 the effect of the margin of error on the interpretation.

\section{Sidi Abed bay (Northeast part) (fig. 3 and fig. 5 (A)):}

145 In the northeast zone (1,500 $\mathrm{m}$ in length), among the 34 transects, 26 show erosion (76.47\%)

146 with an average rate of $-30.62 \mathrm{Lm}$ for the 70 -year period (i.e. $0.44 \mathrm{Lm}$ /year); only 8 transects

147 are under the error margin. 
148 This area has lost approximately $-45,799 \mathrm{~m}^{2}$ (tab. 3). Even if we exclude the values below the

149 margin of error $\left(-15,844 \mathrm{~m}^{2}\right), 65.41 \%$ of the values indicate erosion.

150 In this area, although values inside the margin of error have been excluded, the results still

151 indicate erosion.

152 This tendency of erosion is most probably related to the destruction of the dune and the

153 construction in its place of a group of villas (during the 70s), which today constitute the

154 village of Sidi Abed.

155 Sidi Abed bay (Southwest part) (fig. 3 and fig. 5 (B)):

156 However, in the southwest zone (950 $\mathrm{m}$ in length), from 22 transects only one transect that is 157 outside the margin of error (4.54\%). Even we taking in the account the values inside the 158 margin of error, the rate of accumulation is very low, representing only $5.03 \mathrm{Lm}$ for 70 years 159 (i.e. 0.07 Lm/year).

160 This zone has expanded by $4,892 \mathrm{~m}^{2}$ (tab. 3), but excluding the values inside the margin of

161 error, we find that only $0.63 \%$ (i.e. $31 \mathrm{~m}^{2}$ ) represents a clear accumulation; it means this coast 162 is stable.

163 The south-western zone of Sidi Abed is an area less frequented by tourists and its beach

164 profile comprises the dune fixed by vegetation.

\section{Sidi Moussa beach (fig. 4 and fig. 6):}

166 The site of Sidi Moussa is a rectilinear beach about $2900 \mathrm{~m}$ long. Over the last 70 years, both

167 erosion and accretion was observed; generally, the shoreline is eroding on the southwestern 168 part and accreting on the northeastern part.

169 Among 65 transects, 35 illustrate erosion; the rate of erosion $-7.91 \mathrm{Lm}$ for the 70 years of the 170 study (i.e. $-0.11 \mathrm{Lm} /$ year). The other 30 transects illustrate accumulation with a rate of $9.86 \mathrm{~m}$ 171 (i.e. $0.14 \mathrm{Lm} /$ year). 19 transects are outside the margin of error, which is $29.23 \%$. 
172 The results obtained in this area demonstrate that it is in sedimentary equilibrium; the eroded

173 surface is equal to $12,228 \mathrm{~m}^{2}$ and the added surface is $13,070 \mathrm{~m}^{2}$ (tab. 3). Although the area

174 inside the error interval is very high, the result remains almost the same.

175 At the northeast end of this beach, the growth of the sandy spit clearly demonstrates the 176 movement of sand from southwest to northeast.

\section{5. Conclusions}

178 In addition to demonstrating a new approach for assessing shoreline change, through three

179 case studies, this study clearly demonstrates the effect of taking or not into account the margin

180 of error on the interpretation of the results.

181 The first site, the northeastern part of the Sidi Abed bay, has been subject to significant

182 erosion. Although the margin of error has been taken into account, this site still has signs of

183 erosion.

184 The second site, the south-western part of the Sidi Abed bay, has seen a slight accumulation,

185 but taking into account the margin of error, this site can be interpreted as a stable zone.

186 The evolution of the coastline at the third site, the beach of Sidi Moussa, is more complex;

187 with a south-western zone eroding and a north-eastern zone accumulating. The changes in

188 sediments have been longitudinal (Longshore drift); the area lost to the south-west is almost

189 the same area gained north-east. However, although the margin of error has been taken into

190 account, this site has shown that it is in equilibrium.

191 The monitoring of shoreline changes is very important for local decision-makers for the

192 preparation of development plans. Currently, there are several recent methods of studying

193 coastline evolution, but the use of aerial photographs remains unavoidable for long-term

194 studies. 
195 In mesotidal environments the coastline fluctuation is significant; the identification of HWL

196 on an aerial photographs can still be subject to errors. By taking these errors into

197 consideration, the interpretation of the results becomes more consistent.

\section{Declarations}

199 - Ethics approval and consent to participate

$200 \quad$ 'Not applicable' for that section

- Consent for publication

$\mathrm{KE}, \mathrm{MM}, \mathrm{MH}$ and BZ give their consent for the paper entitled: Influence of the margin of error due to the use of aerial photographs on the interpretation of the shoreline changes: Three cases of study (Atlantic coast of Morocco) to be published in Geoscience Letters.

- Availability of data and materials

The datasets generated during and/or analysed during the current study are available from

207 the corresponding author on reasonable request.

- Competing interests

209 The authors declare that they have no competing interests.

- Funding

211 'Not applicable' for that section

212 - Authors' contributions

$213 \mathrm{KE}, \mathrm{MM}, \mathrm{MH}$ and $\mathrm{BZ}$ conceived and designed the study. KE conducted the literature 214 search. KE and MM conducted the treatment of data using GIS tools. KE, MM, MH and 215 BZ were involved in the analysis and interpretation of data. KE and MM drafted the 216 manuscript. The study was supervised by MH and BZ. All authors read and approved the 217 final manuscript.

218 - Acknowledgements

219 'Not applicable' for that section 


\section{References}

221 Anders FJ, And Byrnes MR (1991) Accuracy of Shoreline Change Rates as Determined from Maps and Aerial Photographs. Shore and Beac (59):17-26.

Bertier J (2009) Analyse multi-échelle de la morphodynamique d'une plage artificielle, avantport ouest de dunkerque (nord de la France). Thèse de doctorat université du littoral côte d'opale France. 303 p.

Boak EH and Turner IL (2005) Shoreline Definition and Detection: A Review. Journal of Coastal Research 21(4):688-703.

Brown I, Jude S, Koukoulas S, Nicholls R, Dickson M and Walkden M (2006) Dynamic simulation and visualisation of coastal erosion. Computers, Environment and Urban Systems 30(2018):840-860.

Chaibi M (2003). Dynamique sédimentaire et morphogenese actuelle du littoral d'El Jadida (Maroc). Thèse 235 p. Université-Aix-Marseille, France.

Crowell M, Leatherman SP and Buckley M.K (1991) Historical Shoreline Change: Error Analysis and Mapping Accuracy. Journal of Coastal Research 7 (3): 839-852.

Dial G (2000) Horizontal accuracy. Imaging notes 15(2):6-7.

Dolan R and Hayden B (1983) Patterns and prediction of shoreline change. In: Komar PD (ed) Handbook of Coastal Processes and Erosion. Boca Raton, Florida: CRC Press, pp.

Durand P (1999) L'évolution des plages de l'ouest du golfe du Lion au xx' siècle. Cinématique $123-149$. du trait de côte, dynamique sédimentaire, analyse prévisionnelle. Thèse $461 \mathrm{p}$. Université Lyon 2, France.

Fletcher C, Rooney J, Barbee M, Lim SC and Richmond B (2003) Mapping shoreline change using digital orthophotogrammetry on Maui, Hawaii. Journal of Coastal Research, pp. $106-124$ 
Furmanczyk K and Dudzinska-Nowak J (2019) Use of aerial photographs for shoreline position and mapping applications. Available from. http://www.coastalwiki.org/wiki/Use_of_aerial_photographs_for_shoreline_position_an d_mamappi_applications

Gibeaut JC, White W, Gutierrez H, Smyth T and Andrews J. (2000) Texas Shoreline Change Project Gulf of Mexico Shoreline Change from the Brazos River to Pass Cavallo. Report, Bureau of Economic Geology, Texas, USA.

Gigout M (1951) Etude géologiques sur la Méséta marocaine occidentale (arrière-pays de Casablanca, Mazagan et Safi). Rapport n 86, 507 p. Trav. Inst. Sc Chérifien, 3, et Not. Mém. Serv. Géol., Rabat, Maroc.

Hilmi K, Orbi A, Lakhdar J, Sarf F and Chagdali M (2002) Etude courantologique descriptive de la lagune de Sidi Moussa (Printemps 1997). In: Actes Colloques Hydrodynamique

Hulme M, Jenkins GJ, Lu X, Turnpenny JR, Mitchell TD and Jones RG (2002) Climate change scenarios for the United Kingdom: The UKCIP02 Scientific Report. Tyndall Centre for Climate Change Research, University of East Anglia Norwich, UK.

Koutistonsky VG, Orbi A, Ouabi M et Ibrahimi I (2006) L'étude du comportement hydrosédimentaire du système lagunaire Oualidia par la modélisation mathématique. Phase 1 : Synthèse des données et simulations de la réfraction des houles. Direction des Ports et du Domaine Public Maritime, Ministère de l'Équipement et du Transport, Royaume du Maroc. $150 \mathrm{p}$.

Murray F (2013) Shoreline changes interpreted from multi-temporal aerial photographs and high resolution satellite images: Wotje Atoll, Marshall Islands. Remote Sensing of Environment (135):130-140. 
Ouadia M (1998) Les formations plio-quaternaires dans le domaine mésétien occidental du Maroc entre Casablanca et Safi: géomorphologie, sédimentologie, paléoenvironnements quaternaires et évolution actuelle. Thèse 277p. Université Mohamed V, Rabat, Maroc.

Pajak MJ and Leatherman S (2002) The high water line as shoreline indicator. Journal of Coastal, 18(2): 329-337. West Palm Beach (Florida), ISSN 0749-0208.

Romine BM, Fletcher CH, Frazer LN, Genz AS, Barbee MM and Lim SC (2009) Historical shoreline change, southeast Oahu, Hawaii; applying polynomial models to calculate shoreline change rates. Journal of Coastal Research, pp. 1236-1253.

Stafford DB (1971) An aerial photographic technique for beach erosion surveys in North Carolina. CERC Technical Memorial 36, 115p.

Sutherland J (2012) Error Analysis of Ordnance Survey Map Tidelines, UK. Proceedings of the ICE -Maritime Engineering 165 (4): 189-197. doi:10.1680/maen.2011.10.

Wernette Ph, Shortridge A, Lusch DP and Arbogast AF (2017) Accounting for positional uncertainty in historical shoreline change analysis without ground reference information. International Journal of Remote Sensing, 38(13):3906-3922. DOI:10.1080/01431161.2017.1303218

Xiaojun Y (Ed.) (2009) Remote Sensing and Geospatial Technologies for Coastal Ecosystem Assessment and Management. Springer-Verlag Berlin Heidelberg, Lecture Notes in Geoinformation and Cartography ISSN: 1863-2246. 560p. 


\section{Figures captions}

292 Fig. 1 Geographic situation and morphological characteristics of the study area coastline

293 Fig. 2 Flowchart of Study

294 Fig. 3 Shoreline change output of Sidi Abed bay (A: without buffer zone; B: with buffer zone)

295 Fig. 4 Shoreline change output of Sidi Moussa beach (A: without buffer zone; B: with buffer

296 zone)

297 Fig. 5 Changes in the shoreline at Sidi Abed bay (1946-2016) (A: Northern part; B: Southern 298 part)

299 Fig. 6 Changes in the shoreline at Sidi Moussa beach (1946-2016)

300 Tab. 1 Data used to cover the study area

301 Tab. 2 Calculated of the error margin of the historical aerial photographs

302 Tab. 3 Calculated of the surfaces inside/outside the margin of error and the rate of variation

303

304

305

306

307

308

309

310

311 


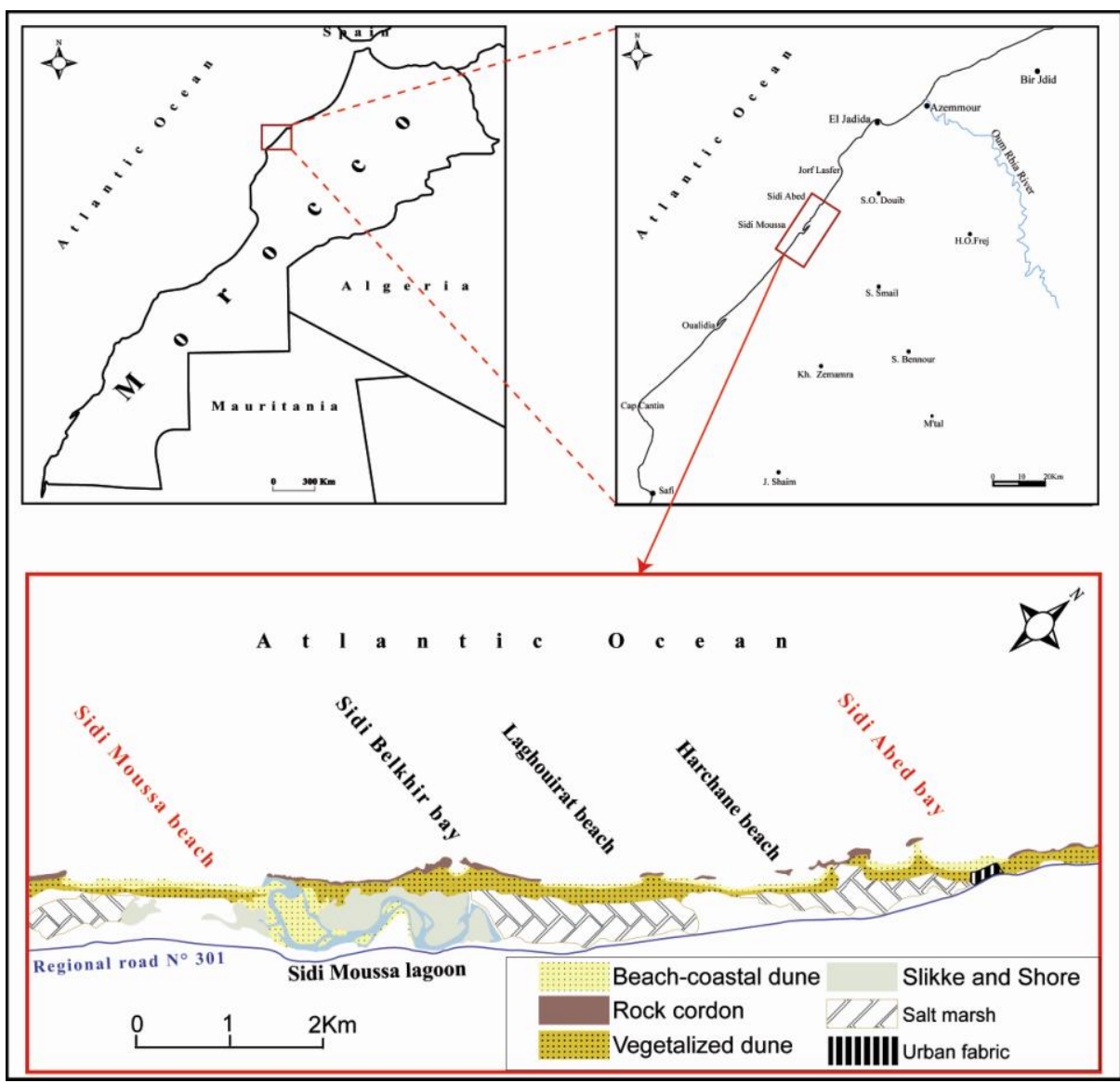

313 Fig. 1 Geographic situation and morphological characteristics of the study area coastline

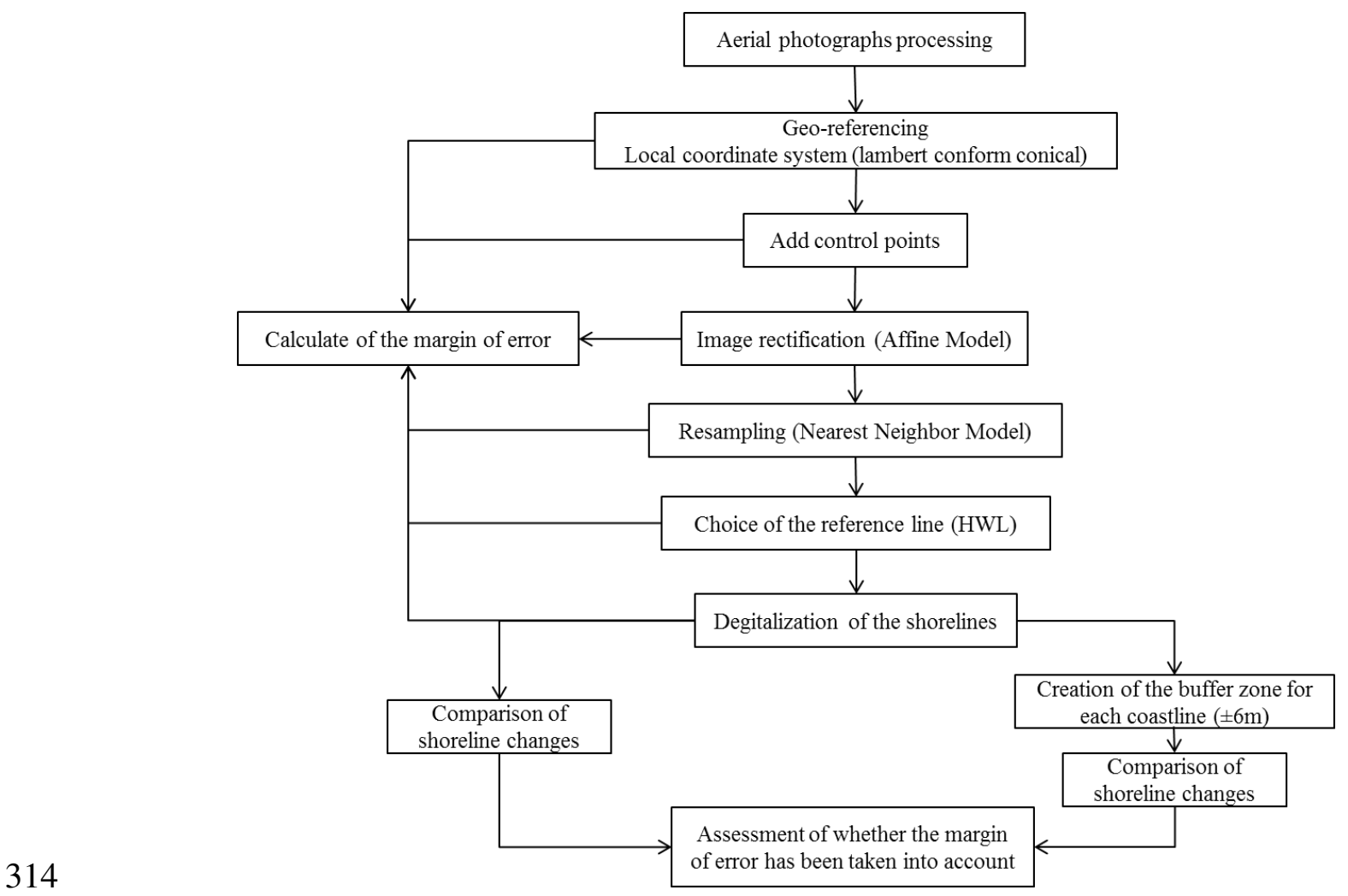

Fig. 2 Flowchart of Study 

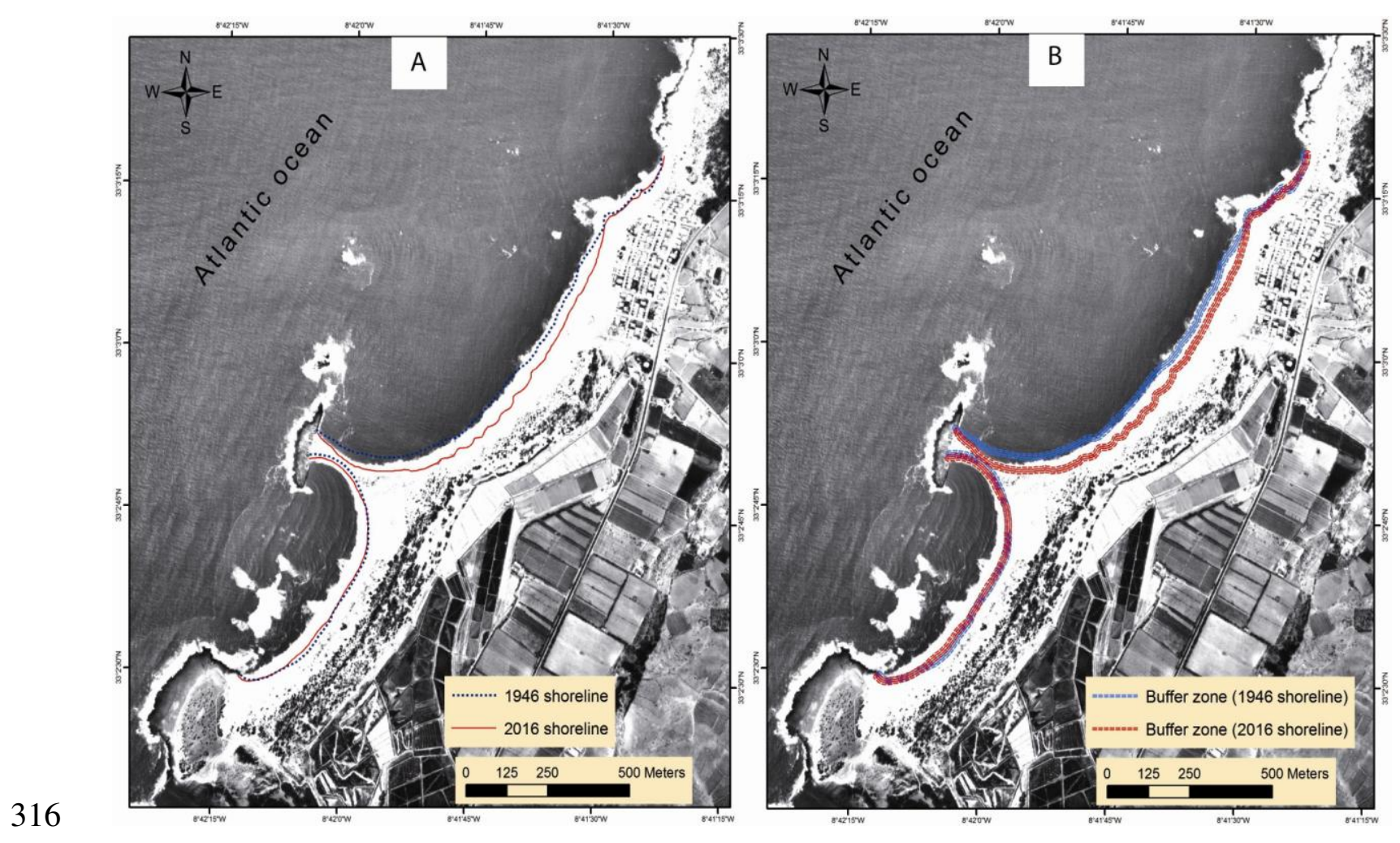

317 Fig. 3 Shoreline change output of Sidi Abed bay (A: without buffer zone; B: with buffer zone)
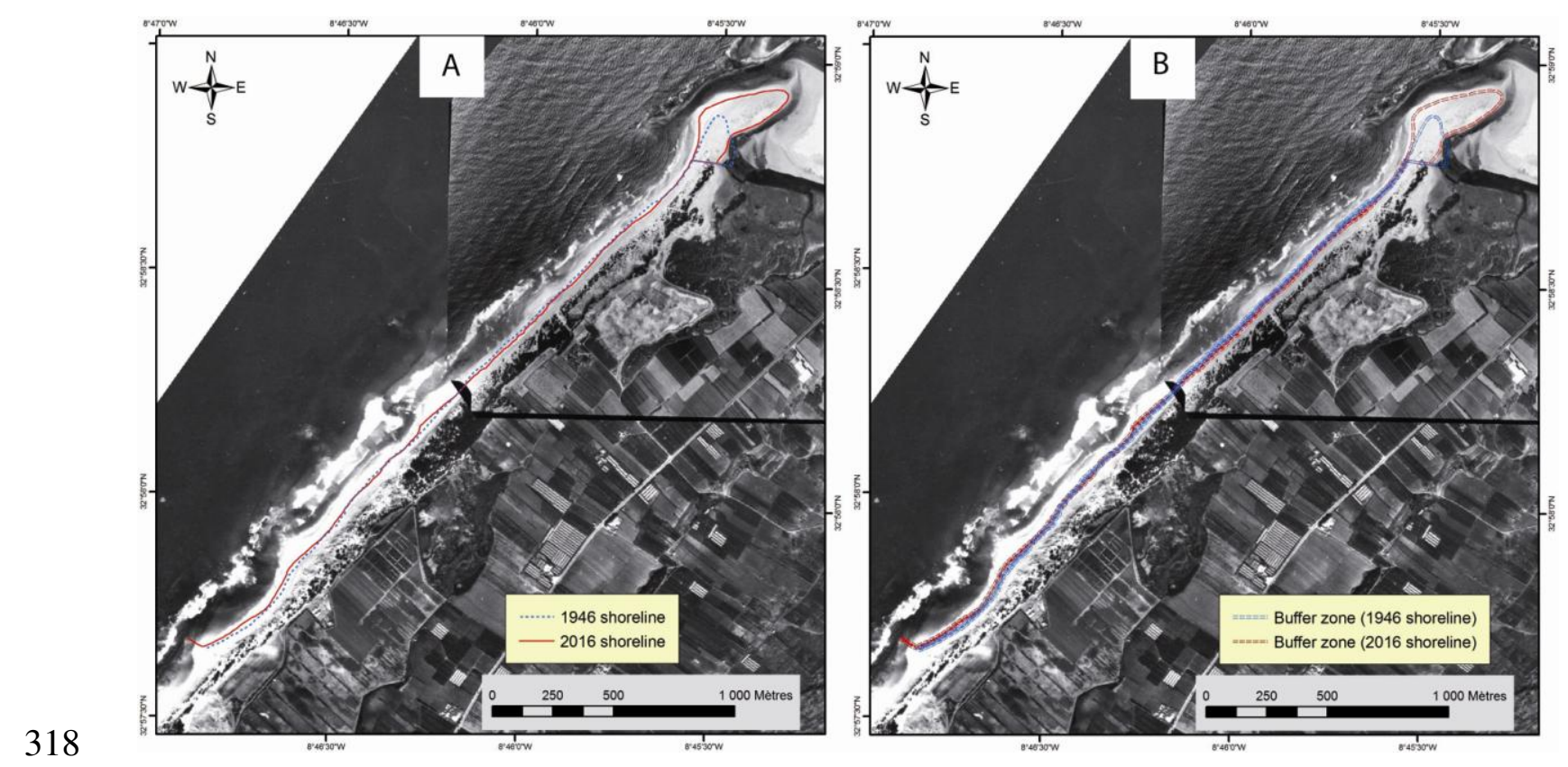

319 Fig. 4 Shoreline change output of Sidi Moussa beach (A: without buffer zone; B: with buffer 

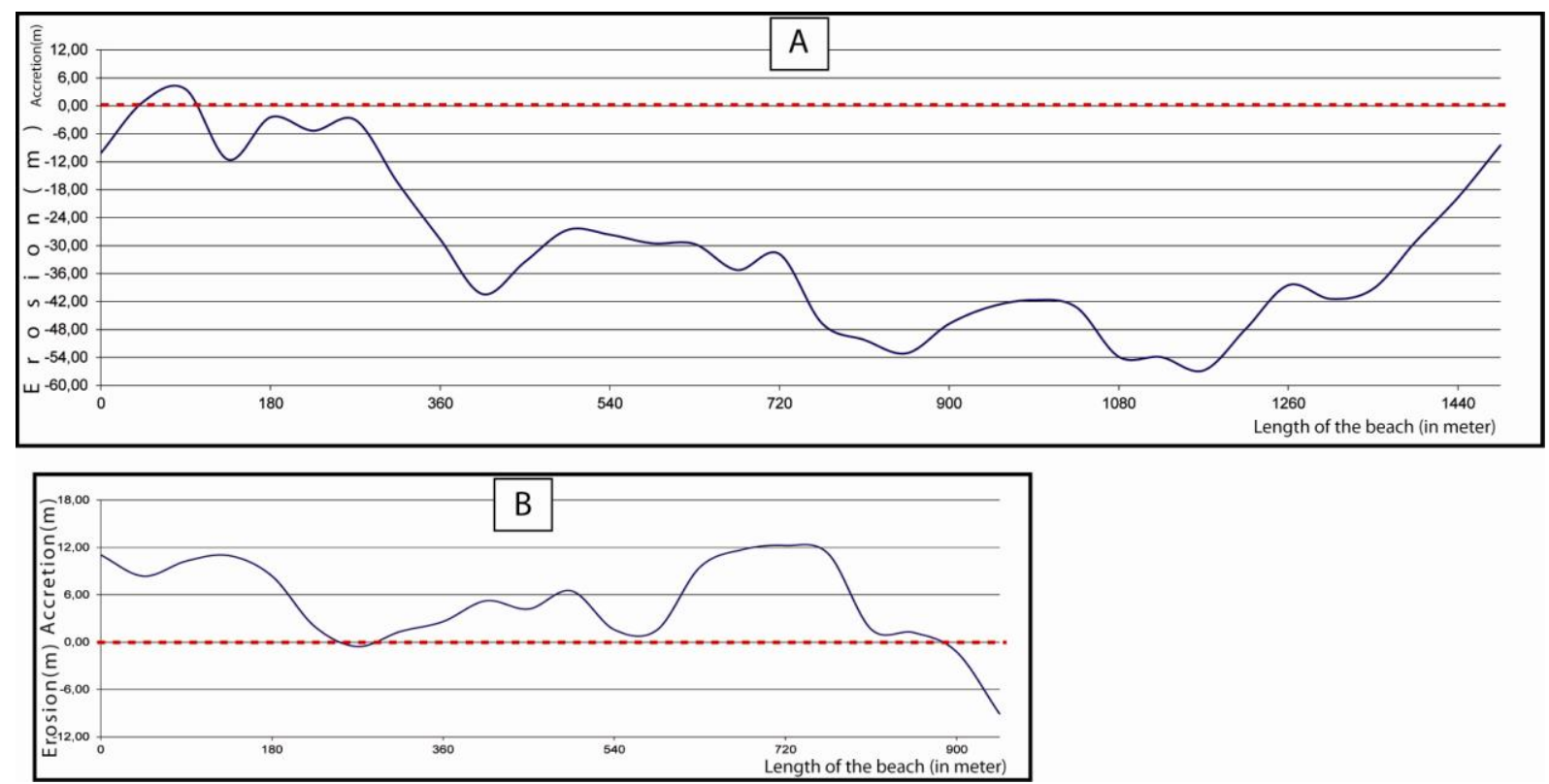

322 Fig. 5 Changes in the shoreline at Sidi Abed bay (1946-2016) (A: Northern part; B: Southern

323 part)

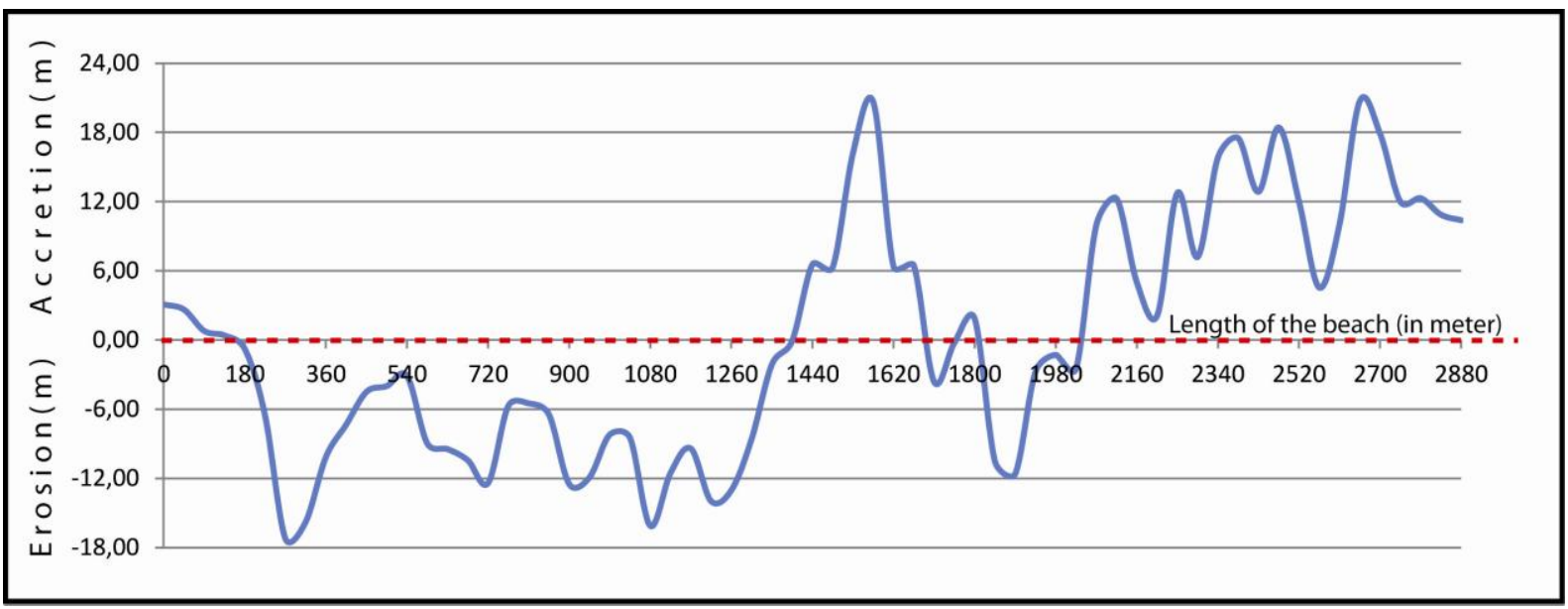

325 Fig. 6 Changes in the shoreline at Sidi Moussa beach (1946-2016)

326 Tab. 1 Data used to cover the study area

\begin{tabular}{|c|c|c|c|c|}
\hline Date & Reference & Scale & Image Type & Number \\
\hline 2010 & ANCFCC $^{*}$ & $1 / 25000$ & Topographic map & 3 \\
\hline $01 / 07 / 1946$ & ANCFCC $^{*}$ & $1 / 33000$ & Black \& white & 3 \\
\hline $05 / 06 / 2016$ & ANCFCC $^{*}$ & $1 / 20000$ & Black \& white & 3 \\
\hline
\end{tabular}

$327 *$ National Agency of Land Conservation of the Cadastre and Cartography 
329 Tab. 2 Calculated of the error margin of the historical aerial photographs

\begin{tabular}{|l|l|c|c|c|c|c|c|}
\hline Site & year & Nb. photos & RMSS & RMSI & RMSV & RMST & RMST95 \\
\hline \multirow{2}{*}{$\begin{array}{c}\text { Sidi } \\
\text { Abed }\end{array}$} & 1946 & 1 & 2.23 & 5 & 3.75 & 6.64 & 11.49 \\
\cline { 2 - 8 } & 2016 & 1 & 1.39 & 5 & 2.12 & 5.61 & 9.70 \\
\hline \multirow{2}{*}{$\begin{array}{c}\text { Sidi } \\
\text { Moussa }\end{array}$} & 1946 & 2 & 3.02 & 5 & 3.15 & 6.64 & 11.49 \\
\cline { 2 - 8 } & 2016 & 2 & 2.66 & 5 & 3.04 & 6,42 & 11.12 \\
\cline { 4 - 8 } & & 2 & 1.85 & 5 & 2.32 & 5,81 & 10.06 \\
\hline
\end{tabular}

Tab. 3 Calculated of the surfaces inside/outside the margin of error and the rate of variation

\begin{tabular}{|c|c|c|c|c|c|}
\hline Sites & $\begin{array}{l}\text { State of the } \\
\text { sectors and } \\
\text { budget }\end{array}$ & $\begin{array}{l}\text { Surface } \\
\mathrm{m}^{2}(\mathrm{~A})\end{array}$ & $\begin{array}{l}\text { Surface inside the } \\
\text { error interval } \mathrm{m}^{2}(\mathrm{~B})\end{array}$ & $\begin{array}{c}\text { Clear difference } \\
m^{2}(C=A-B)\end{array}$ & $\begin{array}{l}\text { Rate of variation in } \\
\%\left(D=C / A^{*} 100\right)\end{array}$ \\
\hline \multirow{3}{*}{$\begin{array}{l}\text { Sidi Abed bay } \\
\text { (northern part) }\end{array}$} & Accretion & 389 & 385 & 4 & 1,03 \\
\hline & Erosion & 46189 & 16230 & 29959 & 64,86 \\
\hline & Budget & -45799 & -15844 & -29955 & 65,41 \\
\hline \multirow{3}{*}{$\begin{array}{l}\text { Sidi Abed bay } \\
\text { (southern } \\
\text { part) }\end{array}$} & Accretion & 5154 & 5120 & 34 & 0,66 \\
\hline & Erosion & 261 & 258 & 3 & 1,15 \\
\hline & Budget & 4892 & 4861 & 31 & 0,63 \\
\hline \multirow{3}{*}{$\begin{array}{l}\text { Sidi Moussa } \\
\text { beach }\end{array}$} & Accretion & 13070 & 11155 & 1915 & 14,65 \\
\hline & Erosion & 12228 & 11515 & 714 & 5,84 \\
\hline & Budget & 841 & -360 & 482 & 57,26 \\
\hline
\end{tabular}


Figures

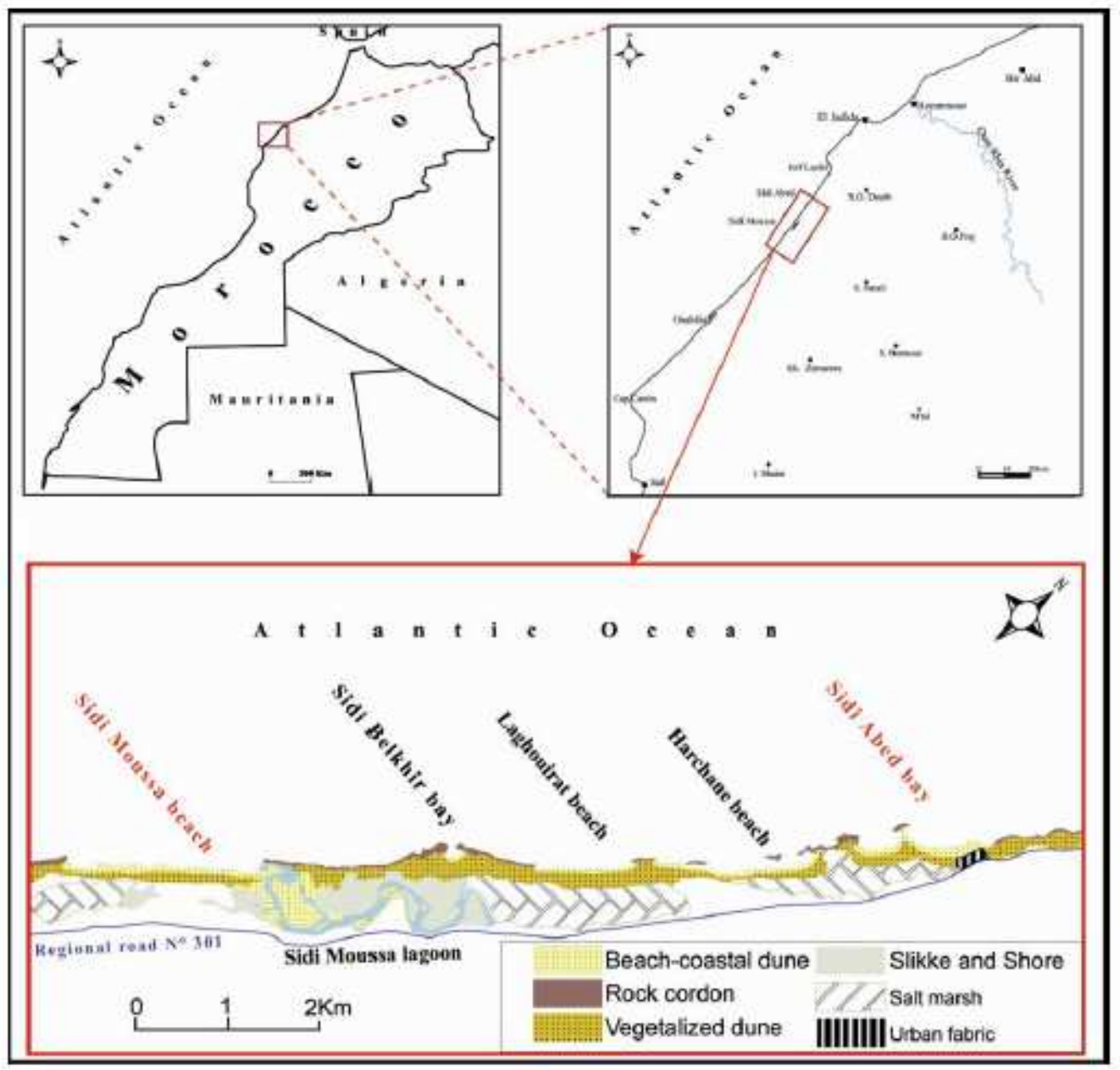

Figure 1

Geographic situation and morphological characteristics of the study area coastline 


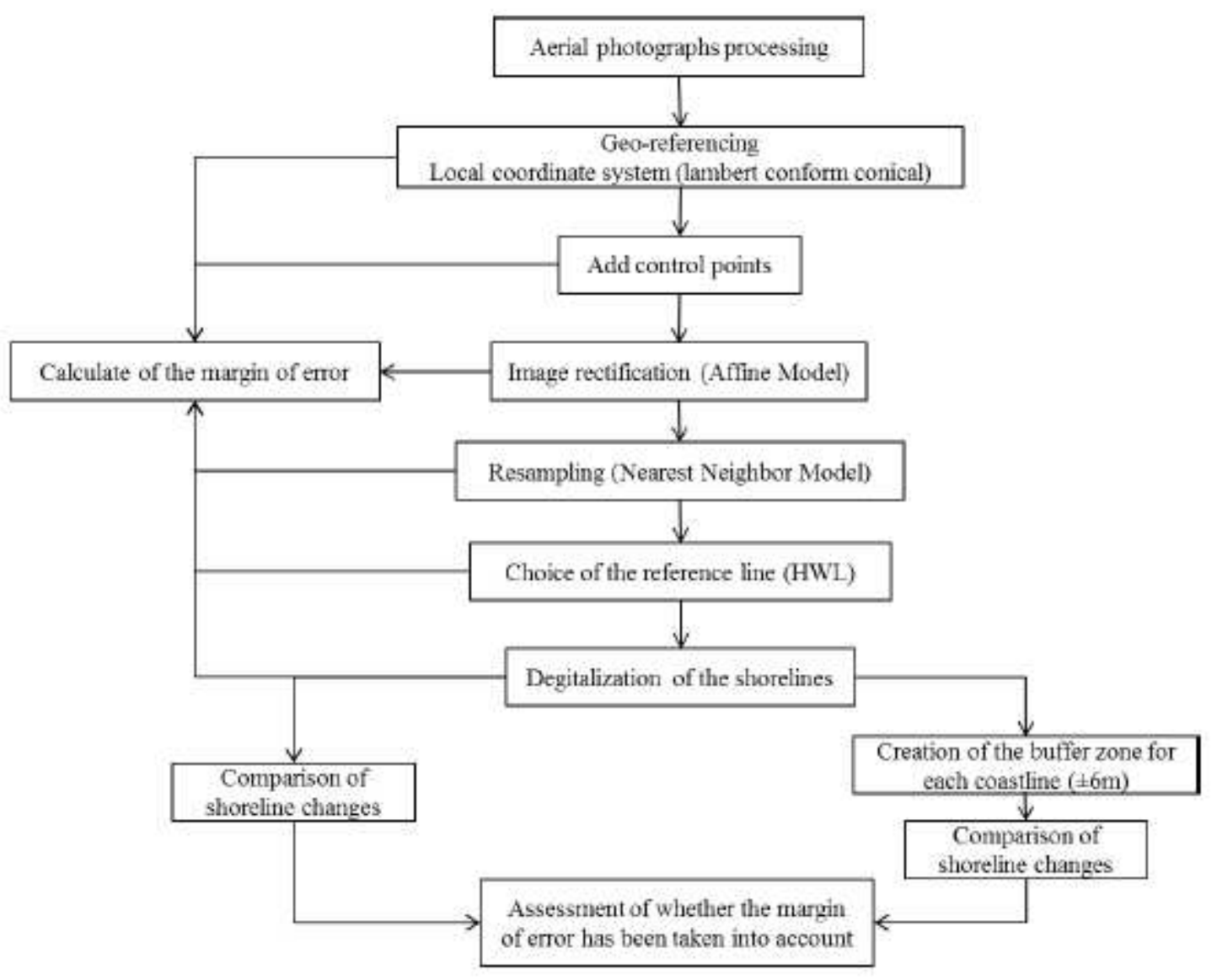

Figure 2

Flowchart of Study 

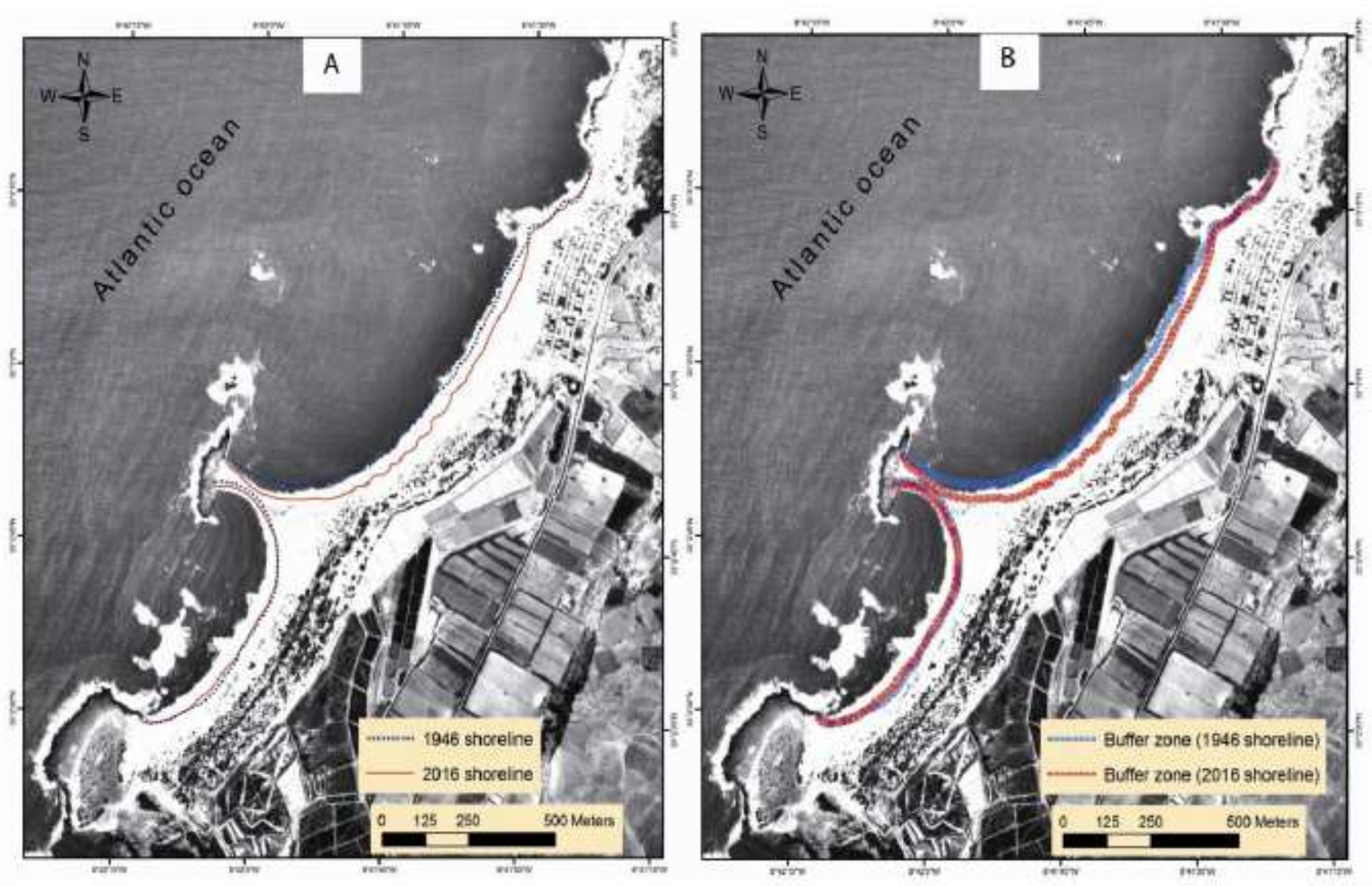

Figure 3

Shoreline change output of Sidi Abed bay (A: without buffer zone; B: with buffer zone)
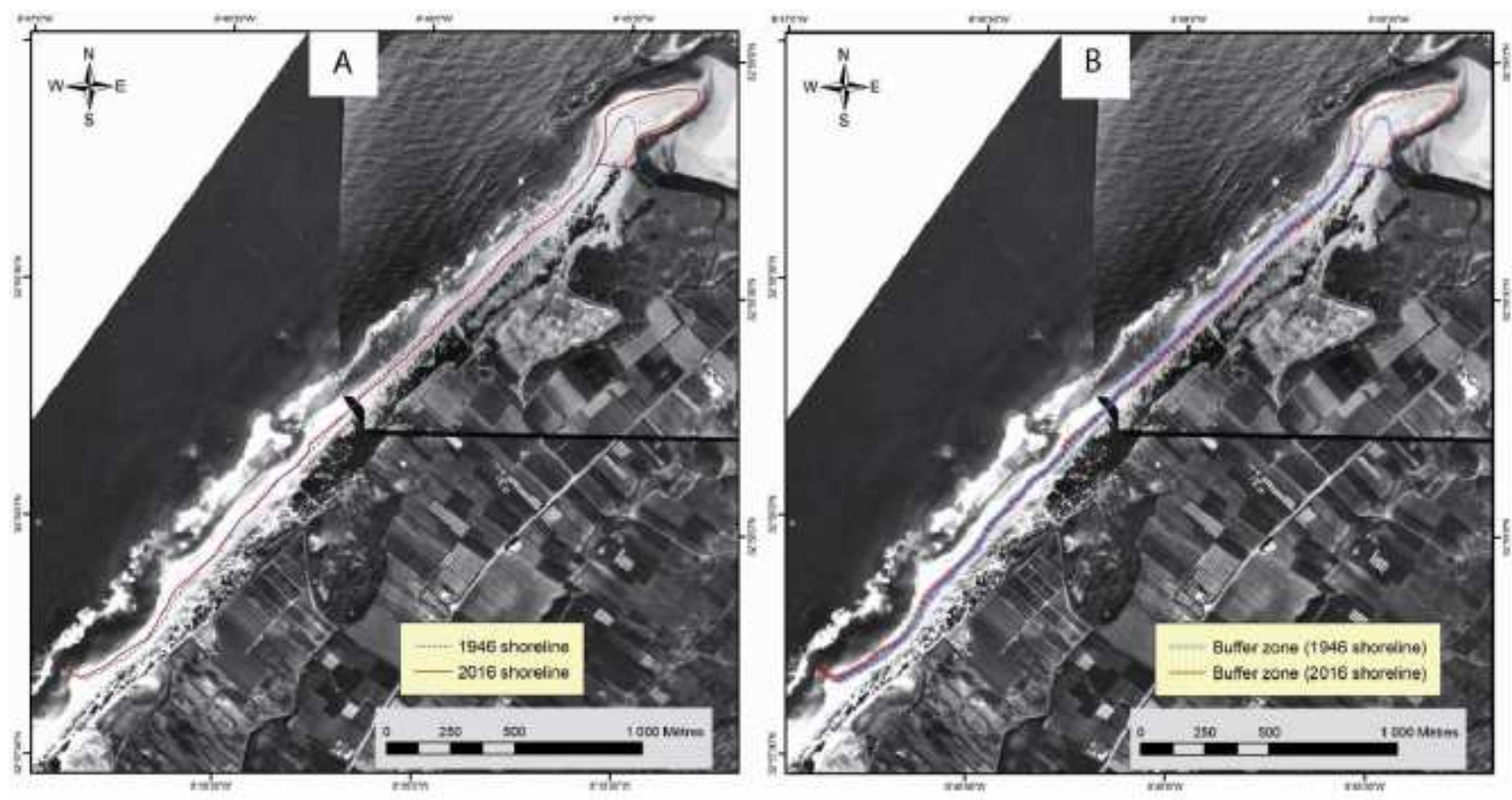

Figure 4 
Shoreline change output of Sidi Moussa beach (A: without buffer zone; B: with buffer zone)
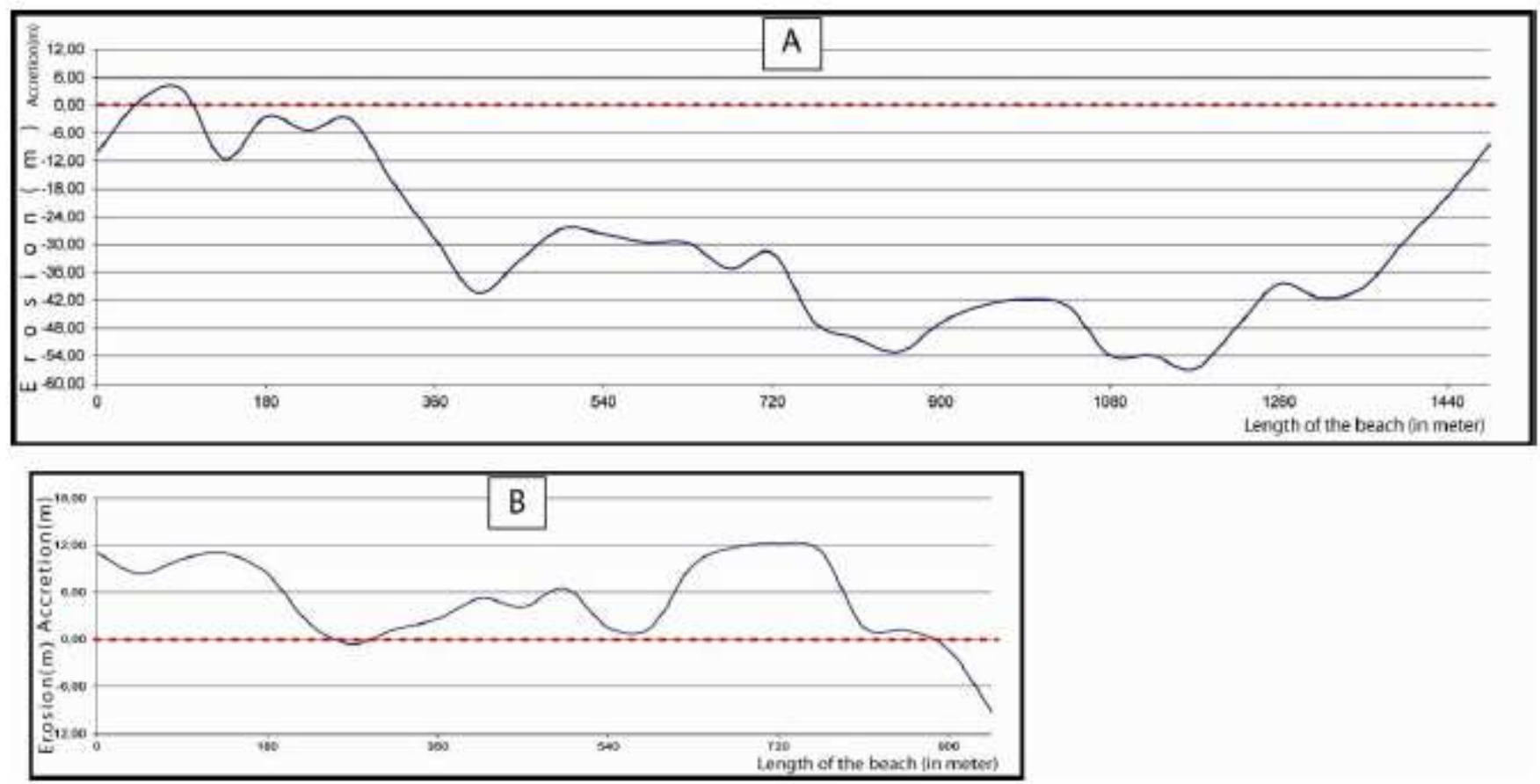

Figure 5

Changes in the shoreline at Sidi Abed bay (1946-2016) (A: Northern part; B: Southern part)

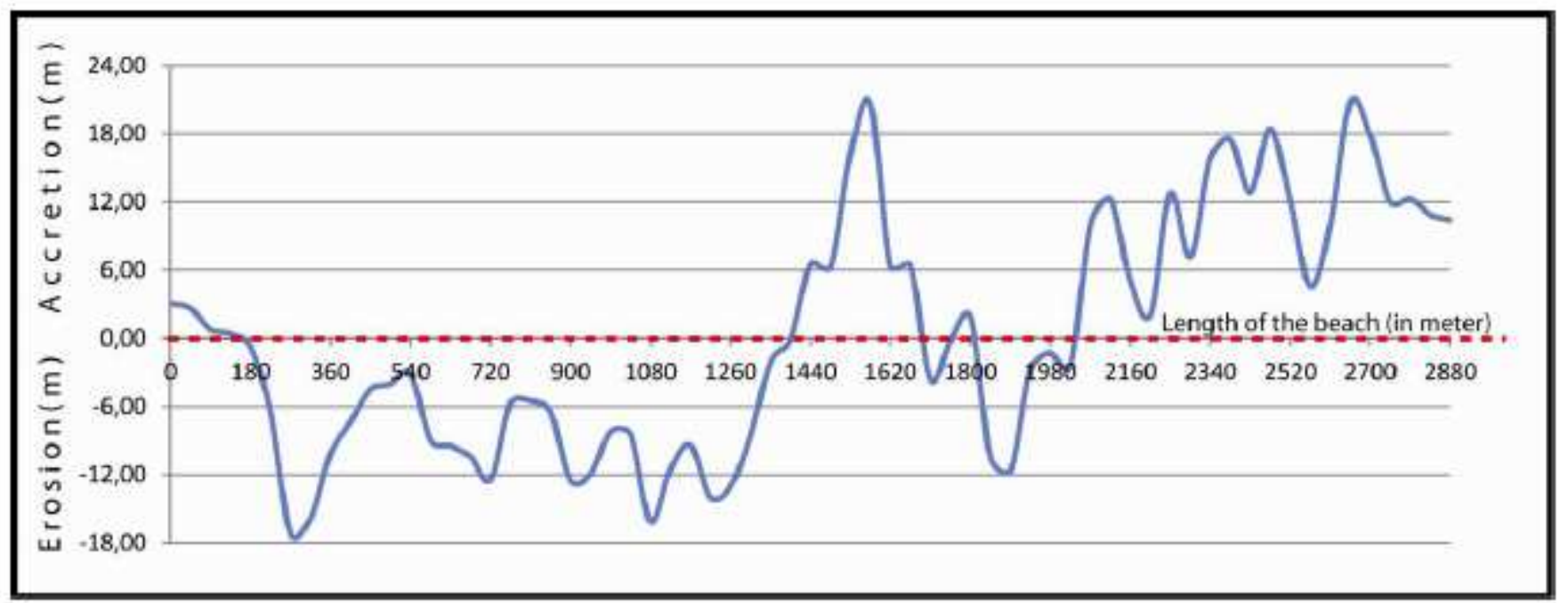

Figure 6

Changes in the shoreline at Sidi Moussa beach (1946-2016) 